\title{
Analisis Faktor Risiko Ergonomi terhadap Keluhan Musculoskeletal Disorders (MSDs) pada Teller Bank
}

\author{
Siti Rahmah Hidayatullah Lubis \\ Program Studi Kesehatan Masyarakat FKIK UIN Syarif Hidayatullah Jakarta \\ J alan Kertamukti No.4, Pisangan, Ciputat Timur, Cireundeu, Ciputat Tim., Kota Tangerang Selatan, Banten 15419 \\ Email : sitirahmah@uinjkt.ac.id
}

\begin{abstract}
Abstrak
Teller bank merupakan kelompok kerja yang berisiko tinggi terhadap keluhan MSDs. Pola kerja mengakibatkan tingkat repetisi pada setiap task tinggi karena waktu setiap transaksi perbankan harus sesingkat mungkin. Penggunaan dan penempatan peralatan kerja lebih kompleks memperbesar risiko Teller bank terhadap keluhan MSDs dibandingkan pada unit kerja lain di bank. Tujuan penelitian ini adalah untuk menganalisis faktor risiko ergonomic terhadap keluhan musculoskeletal disorders pada pekerja Teller bank. Penelitian ini adalah penelitian semikuantitatif dengan menggunakan metode Rapid Entire Body Asessment (REBA) untuk melakukan penilaian risiko ergonomi terhadap 8 task Teller yang menjadi unit analisis penelitian. Untuk mendapatkan keluhan MSDs dilakukan pengisian kuesioner Nordic Body Map terhadap 17 orang Teller Bank di PT. X . Hasil penelitian menunjukkan bahwa task yang menjadi prioritas utama adalah task menyerahkan uang di akhir hari kepada supervisor, tetapi dari data keluhan MSDs dan data peralatan yang didapat prioritas task yang harus segera dilakukan perubahan adalah task menginput data dan task menghitung uang dengan mesin hitung. Berdasarkan analisis lebih lanjut, diketahui faktor yang berkontribusi terhadap timbulnya keluhan MSDs, yaitu : postur statis, postur janggal yang didukung oleh layout yang tidak sesuai dengan standard, dan repetisi yang tinggi dalam melakukan pekerjaan.
\end{abstract}

Kata kunci : Teller Bank, REBA, MSDs

\begin{abstract}
Bank Teller is a high-risk work group for MSDs complaints. Work patterns resulted in a high repetition rate at each task because the timing of each banking transaction should be as short as possible. The function and layout of work equipment is more complex impact to the ergonomic risk more higer than other unit in the organization. The aim of this research wanted to analyze ergonomic risk factors to musculoskeletal disorders on bank Teller complaint. This research is a semiquantitative research used Rapid Entire Body Assesment (REBA) method to assess the ergonomic risk from 8 tasks of bank Teller which become unit of research analysis. Nordic body map used to get a data complaints of MSDs, filled by 17 people Teller Bank in PT. X. The results showed priority task is the task to hand over money to the supervisor at the end of the day, but contradicted with the result of MSDs complaints data and equipment data obtained priority tasks that must be immediately changed is input data and counting money by machine. Based on analysis, factors that contribute to MSDs complaints are: static posture, awkward posture supported by layout of the workstation is not suitable with the standard, and the repetitive job.
\end{abstract}

Keywords : Bank Teller, REBA, MSDs 


\section{Pendahuluan}

Dalam fungsinya sebagai fasilitator untuk memobilisasi dana masyarakat, tentu saja tidak terlepas dari kinerja suatu perbankan. Kinerja suatu perbankan sangat dipengaruhi oleh kinerja pekerjanya terutama Teller sebagai frontliner ,dengan adanya tuntutan yang tinggi terhadap kinerja teller, maka aspek kemudahan dan kenyamanan kerja perlu menjadi perhatian, demi tercapainya efisiensi dan produktifitas kerja yang tinggi.

Teller bank adalah kelompok kerja yang berisiko tinggi terhadap MSDs oleh karena beban kerja fisik dan mental. MSDs seperti work related neck and upper limb disorders dan work related back disorders diketahui berbanding terbalik dengan produktivitas dan kesehatan pekerja. ${ }^{14}$

Postur tidak aman dapat disebabkan oleh disain tempat kerja yang tidak tepat atau prosedur kerja yang tidak standard. Gerakan berputar (twisting) dan membungkuk (bending) pada saat melakukan perhitungan uang dan memeriksa kelengkapan slip transaksi, mencoba menjangkau barang yang terletak cukup jauh (reaching), atau ketika melakukan posisi berdiri ketika mengakhiri transaksi nasabah pun dapat berkontribusi pada kemungkinan timbulnya sakit dan cidera.

Dalam melakukan pekerjaannya, seorang Teller tentu akan menemukan faktor risiko dalam kerjanya, yang bisa mengakibatkan timbulnya penyakit pada diri Teller tersebut. Kelemahan disain ergonomi pada pekerjaan Teller, yang berdampak pada risiko timbulnya kemungkinan gangguan muskoleskeletal, rendahnya produktivitas dan efisiensi kerja, serta kenyamanan bagi Teller maupun nasabah. Risiko tersebut adalah akibat kurang baiknya pengorganisasian disain pekerjaan dan tempat kerja yang tidak ergonomis.

Dalam menjalankan pekerjannya seorang Teller juga rutin bekerja dengan menggunakan komputer, oleh Hargberg ${ }^{3}$ melakukan penelitian ternyata mendapatkan hasil bahwa penggunaan mouse komputer lebih dari 0.5 jam/hari juga merupakan faktor risiko untuk menurunkan produktivitas dan berhubungan dengan terjadinya gejala sakit pada bahu dan tangan. Faktor risiko yang dapat menurunkan produktivitas dan menyebabkan terjadinya gejala musculoskeletal termasuk di dalamnya kurangnya olahraga dan kelebihan berat badan, faktor pekerjaan seperti: lembur, kegiatan kerja yang berlebihan dan penggunaan mouse komputer.

Hwa yun Mung yang melakukan penelitian pada 950 teller bank wanita di Korea, melaporkan bahwa 51.4\% mengeluhkan sakit pada bahu, 38.3\% pada punggung bawah, $38.0 \%$ pada leher, $31.2 \%$ pada punggung atas, $21.7 \%$ pada pergelangan tangan, dan $13.6 \%$ pada jari tangannya. ${ }^{4}$

Sakit punggung merupakan keluhan umum yang sering terjadi pada Teller bank. Berdiri untuk waktu yang lama merupakan kontribusi untuk masalah kesehatan pada pinggang ini. Meskipun para Teller bank di fasilitasi dengan peralatan kursi tetapi belum tentu bisa mencegah sakit punggung pada waktu di masa mendatang. ${ }^{7}$

Berdasarkan observasi awal yang dilakukan terlihat bahwa Teller bank di PT. X dominan banyak melakukan kegiatan yang memungkinkan untuk timbul keluhan MSDs. Beberapa penyebab timbulnya gangguan pada pekerja teller ini, terkait dengan faktor risiko ergonomi pada postur, postur duduk, postur berdiri, gerakan berulang yang dilakukan sangat sering atau dikarenakan adanya tekanan pekerjaan dan lingkungan kerja yang tinggi. Tujuan penelitian ini adalah untuk mengetahui faktor risiko ergonomi, faktor individu dan Tingkat risiko ergonomi pada Teller bank di PT. X kaitannya terhadap keluhan MSDs.

\section{Metode}

Penelitian ini merupakan penelitian deskriptif dengan desain studi cross 
sectional. Pendekatan yang digunakan dalam penelitian ini adalah pendekatan semikuantitatif. Penelitian ini dilakukan di 2 unit kerja yang berbeda pada PT. X. Adapun rentang waktu penelitian adalah Maret hingga April.

Pengumpulan data diperoleh melalui data primer yang dilakukan dengan observasi langsung secara on the spot dengan melakukan : pengamatan Lapangan, wawancara dengan kuesioner Nordic Body Map, pengambilan foto, dan pengukuran antropometri pada 17 orang pekerja Teller Bank yang dianggap mewakili populasi Teller di PT. X.

Metode REBA ergonomic risk assessment tools digunakan untuk mengidentifikasi risiko terhadap bahaya ergonomi yang ada didalam aktivitas kerja secara Direct Observation atau pengamatan langsung terhadap pekerjaan dengan pendekatan task analysis pada pekerja yang dianggap mewakili kelompok pekerja Teller Bank PT. X di Jakarta.

Unit analisis pada penelitian untuk mengukur tingkat risiko ergonomi dengan menggunakan metode REBA adalah: aktivitas kerja dari Teller Bank dalam 1 kali transaksi yang mencakup: Task menyambut nasabah, Task menghitung uang secara manual, Task menghitung uang dengan mesin hitung, Task memeriksa keaslian uang, Task input data transaksi, Task cetak transaksi, Task menyerahkan bukti transaksi kepada nasabah, Task menyetorkan uang di akhir hari kepada supervisor.

Adapun variabel dalam penelitian yaitu faktor risiko ergonomi (postur tubuh, repetisi, durasi, beban) faktor individu (usia, jenis kelamin, pola makan, olah raga, konsumsi vitamin dan susu), dan keluhan MSDs. Data yang dikumpulkan dalam penelitian ini kemudian diolah dan dianalisis dengan analisa secara univariat untuk melihat gambaran setiap variable dalam penelitian. Penyajian data ditampilkan dalam bentuk narasi dan table untuk memperjelas hasil penelitian.
Hasil

\section{Karakteristik Individu}

Hasil univariat untuk karakteristik individu yang meliputi usia, jenis kelamin, lama kerja, kebiasaan pekerja (mencakup : pola makan, olah raga dan kebiasaan meminum vitamin dan susu).

Tabel 1. Distribusi Karakteristik Individu Teller Bank

\begin{tabular}{llcc}
\hline \multicolumn{1}{c}{ Variabel } & \multicolumn{1}{c}{ Kategori } & n & \% \\
\hline Usia & $<25$ tahun & 9 & 52,9 \\
& $\geq 25$ tahun & 8 & 47,1 \\
Jenis kelamin & Perempuan & 17 & 100 \\
& Laki-laki & 0 & 0 \\
Pola Makan & Teratur & 8 & 40 \\
& Tidak teratur & 9 & 60 \\
Olah Raga & Teratur & 5 & 26,7 \\
\multirow{2}{*}{ Vitamin dan } & Tidak teratur & 12 & 73,3 \\
Susu & Teratur & 9 & 53,3 \\
& Tidak teratur & 8 & 46,7 \\
\hline
\end{tabular}

Berdasarkan table 1. Terlihat bahwa berdarkan usia 52,9 \% responden berusia $<25$ tahun. $100 \%$ jenis kelamin adalah perempuan, $60 \%$ memiliki kebiasaan makan tidak teratur, $73,3 \%$ tidak teratur berolah raga dan 53,3\% memiliki kebiasaan minum vitamin dan susu.

\section{Gambaran Tingkat Risiko Ergonomi}

Setelah dilakukan analisa risiko ergonomi pada setiap task Teller seperti pada uraian tabel di bawah ini :

Tabel 2. Gambaran Tingkat Risiko Ergonomi Menurut Task Teller

\begin{tabular}{|c|c|c|}
\hline Task & $\begin{array}{c}\text { Skor } \\
\text { REBA }\end{array}$ & $\begin{array}{c}\text { Tingkat } \\
\text { Risiko } \\
\text { Ergonomi }\end{array}$ \\
\hline Menyambut nasabah & 5 & Sedang \\
\hline $\begin{array}{l}\text { Menghitung uang secara } \\
\text { manual }\end{array}$ & 8 & Tinggi \\
\hline $\begin{array}{l}\text { Menghitung uang dengan } \\
\text { mesin hitung uang }\end{array}$ & 8 & Tinggi \\
\hline Memeriksa keaslian uang & 8 & Tinggi \\
\hline Input data transaksi & 7 & Sedang \\
\hline Cetak transaksi & 4 & Sedang \\
\hline $\begin{array}{ll}\text { Menyerahkan } & \text { bukti } \\
\text { transaksi } & \end{array}$ & 6 & Sedang \\
\hline $\begin{array}{l}\text { Menyetorkan uang kepada } \\
\text { supervisor }\end{array}$ & 9 & Tinggi \\
\hline
\end{tabular}


Berdasarkan Tabel 2. Dari 8 task ada 4 task Teller yang harus menjadi prioritas berdasarkan skor REBA yaitu task menghitung uang secara manual, menghitung uang dengan mesin hitung uang, memeriksa keaslian uang dan menyetorkan uang kepada supervisor karena memiliki kategori skor tinggi.

\section{Keluhan Muskuloskeletal disorders} (MSDs)

Dari keseluruhan kuesioner yang disebarkan kepada Teller Bank yang bekerja di PT. X, dan setelah dilakukan pengisian terlihat distribusi keluhan muskuloskeletal disorders (MSDs) seperti terlihat pada tabel berikut ini :

Tabel 3. Distribusi Frekuensi Keluhan MSDs pada Teller Bank PT. X

\begin{tabular}{lcc}
\hline \multicolumn{1}{c}{ Keluhan MSDs } & n & \% \\
\hline Ada keluhan & 15 & 88,3 \\
Tidak ada keluhan & 2 & 11,7 \\
\hline
\end{tabular}

Berdasarkan table 3. Dari pengisian kuesioner Nordic Body Map terdapat $88,3 \%$ atau sekitar 15 orang responden mememiliki keluhan musculoskeletal disorders.

Tabel 5. Distribusi Jumlah Keluhan Musculoskeletal Disorders (MSDs) Pada Teller Bank Berdasarkan Jenis Bagian Tubuh

\begin{tabular}{lcccc}
\hline \multirow{2}{*}{ Jenis Keluhan } & \multicolumn{2}{c}{ Ya } & \multicolumn{2}{c}{ Tidak } \\
\cline { 2 - 5 } & $\mathbf{n}$ & $\mathbf{\%}$ & $\mathbf{n}$ & $\mathbf{\%}$ \\
\hline Leher & 13 & 86,7 & 2 & 13,3 \\
Bahu & 13 & 86,7 & 2 & 13,3 \\
Siku & 4 & 26,7 & 11 & 73,3 \\
Perg. Tangan & 6 & 40 & 9 & 60 \\
Lengan tangan & 8 & 53,4 & 7 & 46,6 \\
Punggung atas & 8 & 53,3 & 7 & 46,7 \\
Punggung tengah & 7 & 46,7 & 8 & 53,3 \\
Punggung bawah & 6 & 40 & 9 & 60 \\
Pinggang & 9 & 60 & 6 & 40 \\
Paha & 4 & 26,7 & 11 & 73,3 \\
Lutut & 5 & 33,3 & 10 & 66,7 \\
Betis & 6 & 40 & 9 & 60 \\
Pergelangan kaki & 7 & 46,7 & 8 & 53,3 \\
Telapak kaki & 7 & 46,7 & 8 & 53,3 \\
\hline
\end{tabular}

Berdasarkan hasil kuesioner Nordic Body Map tentang keluhan MSDs yang terlihat pada table 4. Di atas keluhan paling banyak terdapat pada leher dan bahu yang diikuti dengan keluhan pada pinggang. Keluhan paling rendah terdapat pada pergelangan tangan, lutut dan betis.

\section{Pembahasan \\ Analisa Risiko Ergonomi}

Analisis risiko ergonomi dilakukan terhadap task Teller dalam melakukan 1 kali transaksi secara berurutan. Metode yang digunakan dengan metode REBA. Hasil analisa seperti yang dipaparkan pada table 1, bahwa ada 4 task yang berisiko tinggi, dan 4 task berisiko sedang. Dalam analisa secara metode REBA terlihat bahwa kebanyakan dalam melakukan pekerjaan nya Teller lebih banyak menggunakan otot kecilnya yaitu pada anggota tubuh kelompok $\mathrm{B}$, yaitu pada lengan atas, lengan dan pergelangan tangannya. Diperbesar dengan frekuensi task yang dilakukan sering lebih dari 4 kali dalam 1 menit.

Terlihat pada metode REBA ini, bahwa task menyetorkan uang di akhir hari kepada supervisor merupakan task dengan kategori risiko paling tinggi, hal ini jika dianalisa dengan metode REBA timbul dikarenakan pada saat dilakukannya task ini memerlukan energy yang cukup besar karena dikombinasikan dengan mengangkat beban yang mencapai $5 \mathrm{~kg}$ pada saat mengangkat uang ke ruang supervisor, dan didukung oleh postur yang terlihat janggal pada saat memasukkan uang ke dalam brankas uang, yaitu melakukan postur jongkok dalam durasi yang cukup lama, tetapi task ini tidak memiliki frekuensi yang cukup tinggi, hanya dilakukan sekitar 2-3 kali dalam 1 hari kerja.

Berbeda halnya dengan analisis berdasarkan data keluhan MSDs Teller yang dirasakan oleh pekerja Teller yang umumnya merasakan keluhan pada anggota tubuh leher, bahu dan pinggang. Jika dilihat dari keluhan yang dirasakan oleh pekerja Teller tentu terlihat bahwa task input data merupakan task yang paling berbahaya dengan tingkat risiko ergonomi 
yang cukup tinggi pada anggota tubuh bahu dan tangan. Terlihat dari postur janggal yaitu bending saat mengetik di komputer, postur leher yang tidak sesuai, dan terutama pada posisi lengan yaitu siku yang tidak berada pada sudut 90 derajat, dikarenakan tidak adanya arm support dan rendahnya meja Teller sehingga membuat lengan tidak berada pada kondisi yang ergonomi, posisi pergelangan tangan yang terus menerus berdeviasi pada saat mengetik didukung dengan durasi yang paling lama dan frekuensi yang paling tinggi pada analisis berdasarkan keluhan MSDs seharusnya menjadi task yang paling berbahaya, sehingga menjadi focus task yang harus segera dilakukan perbaikan untuk mengurangi bahaya yang bisa terjadi pada Teller.

Kemudian juga berdasarkan data keluhan MSDs terlihat bahwa anggota tubuh pinggang merupakan keluhan yang cukup dirasakan sering oleh Teller, jika dikaitkan terlihat bahwa task menghitung uang dengan mesin hitung merupakan task yang paling berbahaya untuk daerah pinggang, hal ini dikarenakan task menghitung uang ini sering dilakukan dalam postur duduk, dengan pinggang memutar (twisting) dan tangan dipaksakan untuk menjangkau keluar ke arah belakang kanan/kiri untuk menjangkau mesin hitung. Didukung oleh durasi yang cukup lama, dan frekuensi yang sering menyebabkan task ini menjadi task yang cukup berbahaya dari sudut pandang ergonomi terhadap keluhan MSDs di pinggang.

Data dari keluhan MSDs ini jika dikaitkan dengan data peralatan terlihat keselarasan, bahwa ketinggian meja yang terlalu rendah, kursi yang tidak dapat diatur ketinggiannya dan tidak memiliki fasilitas kursi yang nyaman, penempatan monitor di bawah meja yang tidak sesuai dengan standard kenyamanan, tray keyboard yang terlalu sempit dengan ketinggian yang tidak sesuai, ruang gerak mouse yang terbatas, penempatan mesin hitung yang kurang menjangkau bagi posisi Teller, hingga tidak adanya document holder sebagai tempat dokumen pada saat mengetik yang bisa membantu mengurangi kelelahan mata pada saat mengetik menjadi faktor yang semakin menambah untuk timbulnya keluhan MSDs pada Teller terutama keluhan pada anggota leher, bahu dan pinggang.

Kaitan keluhan MSDs ini dikarenakan layout dan dimensi peralatan yang digunakan sejalan dengan penelitian yang menemukan pada pekerja kantoran umumnya akan timbul keluhan pada leher yang disebabkan duduk dalam durasi yang lama. Hughes dalam penelitiannya menyatakan bahwa pada pekerja yang sering mengetik akan timbul keluhan MSDs pada upper extremity yang umumnya adalah leher dan bahu ${ }^{4}$. Penelitian lain juga menemukan bahwa pada Teller akan cenderung mengalami keluhan pada tubuh bagian atas, tubuh bagian bawah dan pinggang terkait dengan postur duduk dan berdiri yang dilakukan dalam jangka waktu yang panjang. ${ }^{14}$

Kontraksi otot terjadi pada saat tubuh bergerak, kontraksi otot memerlukan suplai energy yang banyak yaitu membutuhkan ATP (Adenosine Tripohosphate) dan kalsium. Ketika ATP dikonsumsi oleh otot yang berkontraksi, dia akan diganti dengan cara metabolisme anaerobic, yaitu metabolisme bahan bakar tanpa adanya oksigen. Jika oksigen tidak ada, penghancuran bahan bakar secara penuh tidak mungkin terjadi, dan asam laktat akan terbentuk. Akumulasi dari asam laktat mungkin bertanggung jawab terhadap nyeri pada otot yang berhubungan dengan kerja keras. Jika otot terus berkontraksi tidak ada kesempatan untuk relaksasi maka akan terjadi kelelahan pada otot. $^{8}$

Pada task yang dilakukan Teller umumnya melibatkan otot-otot pada leher, bahu dan pergelangan tangan, karena pada task input data misalnya, Teller harus mencondongkan badannya dengan kepala menunduk atau melibatkan otot-otot pada leher yaitu otot Sternocleidomastoideus, 
otot Trapezius yang bisa membuat kepala berotasi dan memfleksikan dan menundukkan kepala. Otot Trapezius juga bertanggung jawab untuk mengangkat bahu saat berkontraksi yang juga dibantu otot Serratus anterior dalam menggerakkan bahu. Tetapi terdapat juga otot Pectoralis mayor, latissimus dorsi, Deltoid dan otot-otot di sendi bahu yang berkontraksi untuk menggerakkan bahu.

Pada Task yang melibatkan gerakan lengan bawah terdapat otot Triceps brachii, Biceps brachii, Brachialis dan Brachioradialis yang mendukung berat tubuh dan membantu memfleksikan lengan bawah pada saat bekerja dan berkegiatan.

Pada task menginput data, atau task menghitung uang secara manual banyak mempergunakan otot-otot yang menggerakkan tangan dan jari-jari. Terdapat lebih dari 20 otot yang menggerakkan tangan dan jari-jari pada saat bekerja yang terdiri dari otot Fleksor dan Ekstensor. Jika terjadi kekakuan pada jari-jari tangan maka perlu dilakukan latihan pasif dari tangan dan jari-jari.

Teller pada saat bekerja juga melibatkan otot penggerak paha, tungkai dan kaki. Terutama dilakukan pada task menyambut nasabah, task memeriksa keaslian uang yang mengharuskan Teller untuk berdiri. Otot yang bekerja pada task ini adalah otot gluteus, Iliopsoas, dan sekelompok otot Adductor. Otot ini termasuk ke dalam otot-otot yang terbesar dan terkuat yang ada di dalam tubuh. Otot ini tidak hanya berperan pada saat berdiri terutama otot Gluteus yang berperan pada saat duduk, meluruskan, dan mengekstensikan paha pada panggul. Dan terdapat otot yang memfleksikan lutut yang juga didukung oleh otot kelompok quadriceps femoris, Sartorius yang berfungsi mengekstensikan dan meluruskan tungkai pada lutut.

Kebutuhan gizi dan nutrisi yang cukup tentu sangat menentukan baik buruknya kerja dari otot pada tubuh. Konsumsi vitamin seperti Vitamin C, Kalsium bisa sangat membantu dalam proses metabolisme otot dan membantu meningkatkan kepadatan tulang. sehingga tingkat risiko keluhan MSDs dapat dikurangi seiring dengan pemenuhan kebutuhan gizi dan nutrisi yang seimbang. ${ }^{13}$

\section{Postur Janggal}

Pekerjaan Teller sarat dengan postur janggal yang tidak akan mungkin bisa dihindari dalam keseharian mereka bekerja. Seperti pada task menyambut nasabah terlihat pada saat penelitian bahwa terjadi postur janggal pada punggung yang condong ke depan bersandar kepada tone bank yang jarak jangkauan dari Teller agak jauh, dan posisi bahu terangkat dan siku tertekuk. Hal ini dapat menyebabkan anggota tubuh badan terutama bagian belakang dan lengan menjadi lelah dan tidak nyaman.

Untuk task menghitung uang secara manual yang dilakukan pada posisi duduk maupun berdiri terlihat postur janggal pada anggota tubuh kepala yang menunduk karena focus kepada uang yang digenggam di tangan kiri, dan lengan menggantung untuk terus menghitung uang dan pergelangan tangan berdeviasi dikombinasikan dengan frekuensi yang sangat sering dalam kerja jari menghitung uang. Postur tersebut dapat menyebabkan leher dan lengan menjadi lelah dan tidak nyaman.

Task menghitung uang dengan mesin hitung yang juga dilakukan terkadang dengan posisi duduk maupun berdiri, postur janggal terjadi didukung oleh penempatan mesin hitung yang terletak di samping kanan belakang Teller. Sehingga Teller harus memutar (twisting) badannya ke arah mesin hitung, dan tangan bergerak ke arah luar mengarah ke mesin, dalam waktu yang singkat berbalik lagi ke arah normal. Hal ini dilakukan dalam waktu yang singkat dan frekuensi sering. Faktor risiko repetisi berkombinasi dengan postur janggal akan menyebabkan otot pada punggung dan lengan bisa terjadi keluhan MSDs dan rasa tidak nyaman. 
Task memeriksa keaslian uang dengan menggunakan lampu sinar UV (Ultra Violet) terjadi postur janggal badan membungkuk (bending) dan twisting ke arah samping kiri, hal ini terjadi karena penempatan lampu sinar UV diletakkan di sudut kiri meja kerja Teller dikarenakan banyaknya peralatan yang terletak di atas meja sehingga Teller harus menjangkau ke arah lampu sinar UV yang terlihat di luar jangkauan normal Teller. Postur untuk lengan juga dipaksakan untuk mencapai kearah lampu dan postur janggal ini terjadi dalam waktu yang cukup lama kurang lebih 1 menit tergantung dari banyaknya uang yang diperiksa diperiksa selembar demi selembar. Hal ini bisa menimbulkan keluhan MSDs dan rasa tidak nyaman pada otot punggung dan lengan yang menggantung.

Task input data terlihat postur janggal punggung condong ke depan disebabkan karena penempatan monitor yang terletak di bawah meja Teller jadi untuk melihat ke arah monitor Teller harus mencondongkan badannya, dan pada task ini punggung Teller tidak pernah bersandar pada sandaran punggung kursi. Lengan juga terlihat tidak sejajar membentuk sudut $90^{\circ}$ karena letak tray keyboard yang terlalu rendah dengan postur tubuh Teller yang tidak terlalu tinggi menyusahkan baginya untuk mensejajarkan lengannya dengan posisi keyboard dan mouse. Ketinggian meja kerja Teller yang rendah juga memberikan kontribusi pada tubuh untuk melakukan postur janggal karena meja yang terlalu rendah menyebabkan gerak tubuh Teller tidak bisa bebas terutama kaki karena ketinggian meja sama dengan tinggi paha Teller. Kondisi seperti ini bisa menyebabkan kelelahan dan ketidaknyamanan pada anggota tubuh leher dan bahu, sehingga diperlukan untuk melakukan perubahan pada tinggi meja kerja Teller.

Pada task cetak transaksi terlihat postur janggal terutama pada lengan kiri karena harus menempatkan slip transaksi ke dalam passbook printer yang terletak di pinggir kiri meja kerja Teller. Posisi dari passbook printer ini sedikit mengganggu, karena sempitnya meja kerja ditambah dengan peralatan passbook printer ini membuat lengan harus bergerak kea rah kiri luar dan siku tertekuk, sehingga perlu di ubah penempatan mesin passbook printer ini untuk mengurangi risiko ergonomic pada lengan kiri dan punggung yang harus twisting kearah kiri.

Untuk task menyerahkan bukti transaksi kepada nasabah postur janggal hampir sama dengan task menyambut nasabah, hal ini dikarenakan pada task ini Teller harus berdiri mencondongkan tubuh ke tone bank mendekati nasabah karena Teller bertugas untuk menjelaskan jenis transaksi dan pembukuan yang sudah dilakukan sampai nasabah cukup jelas dengan penjelasan Teller tersebut. Postur janggal ini terlihat juga pada lengan yang terangkat menopang tubuh di meja tone bank, postur ini terjadi dalam waktu yang cukup lama sehingga memungkinkan untuk timbulnya keluhan dan rasa tidak nyaman pada tubuh Teller.

Pada task menyetorkan uang di akhir hari kepada supervisor terjadi kombinasi antara faktor risiko postur janggal dengan beban yang diterima Teller, karena pada task ini kegiatan Teller mengangkat dan membawa tumpukan uang yang akan disetor biasanya berat sekitar $\pm 5 \mathrm{~kg}$, dan jika banyak disesuaikan dengan kemampuan Teller untuk membawa tumpukan uang yang akan disetor. Postur janggal terlihat pada tangan dan bahu yang terangkat karena menopang uang yang akan dibawanya, dan terlihat Teller melakukan postur jongkok selama beberapa waktu, karena brankas uang supervisor terletak di bawah dan diruangan supervisor yang terletak terpisah dengan ruangan Teller. Kepala harus menunduk karena harus konsentrasi dengan jumlah uang yang disetor ketelitian menjadi yang utama. Hal ini bisa menyebabkan kelelahan pada otot punggung dan bahu karena harus berjongkok dan membawa beban tumpukan uang. 
Kondisi peralatan kerja seperti yang dipaparkan pada bagian di atas terlihat secara tidak langsung menyebabkan Teller harus melakukan postur janggal diluar dari prosedur kerja yang juga mengharuskan mereka berpostur janggal. Sehingga perlu dilakukan perubahan yang menyeluruh pada peralatan kerja Teller seperti perubahan meja kerja Teller, kursi kerja dan layout dari area kerja Teller untuk mengurangi risiko ergonomi kerja pada pekerjaan Teller.

\section{Repetisi}

Pekerjaan Teller dalam kesehariannya selalu melakukan postur kerja yang janggal secara berulang sepanjang waktu. Gerakan berulang terjadi lebih dari 4 kali dalam 1 menit sepanjang waktu kerja. Hal ini tentu sangat berisiko terhadap terjadinya gejala MSDs pada Teller yang sarat dengan penggunaan komputer dalam bekerjanya.

Gerakan berulang ini tidak dapat dihindari dikarenakan tuntutan pekerjaan mengharuskan mereka untuk melakukan gerakan repetisi, namun dapat diminimalisasi faktor risiko nya dengan melakukan perbaikan pada layout area kerja dan peralatan kerja.

\section{Durasi}

Pekerjaan berlangsung dimulai dari pukul 08.00 hingga 15.00 transaksi untuk melayani nasabah ditutup, akan tetapi pekerjaan terus berlangsung normalnya sampai pukul 17.00 untuk menyelesaikan daftar mutasi harian. Jikalau ada pekerjaan internal Customer Service juga akan dibantu oleh para Teller yang biasanya bisa sampai pukul 20.00 malam. Durasi istirahat biasanya 1 jam perhari dimulai pukul 12.00 - 13.00 untuk Teller pertama, dan dilanjutkan istirahat pukul 13.00 14.00 untuk Teller berikutnya.

Untuk istirahat kecil diluar waktu istirahat sebenarnya tidak pernah atau jarang dilakukan oleh Teller, dikarenakan terbatasnya waktu dan padatnya transaksi yang harus mereka kerjakan. Untuk itu perlu disisipkannya waktu untuk beristirahat kecil setidaknya untuk melakukan stretching, karena jika faktor durasi berkombinasi dengan faktor repetisi, maka durasi akan menjadi faktor risiko juga terhadap terjadinya gejala MSDs karena repetisi yang dilakukan lebih dari 4 kali dalam 1 menit selama lebih dari 2 jam yang dapat menyebabkan kelelahan pada otot.

\section{Beban}

Dalam bekerja, Teller kebanyakan bertugas input data, menghitung uang, memeriksa kelengkapan transaksi dan mencetak transaksi. Tidak terlalu melibatkan beban yang berlebihan ( $>5 \mathrm{~kg}$ ). Hanya pada task Menyetorkan uang di akhir hari kepada supervisor yang melibatkan factor beban, karena pada task ini Teller bertugas untuk mengangkat sejumlah uang yang jumlahnya sangat banyak yang terkadang bisa mencapai $5 \mathrm{~kg}$ berat tumpukan uang yang harus di angkat Teller. Tetapi di luar itu bisa diambil kesimpulan bahwa factor beban tidak menyebabkan risiko yang terlalu berarti untuk terjadinya gejala MSDs pada Teller bank di PT. X.

Kesimpulan Terlihat bahwa, ada ketidak selarasan antara hasil dari analisa risiko ergonomic metode REBA dengan data keluhan MSDs pada Teller. Hal ini terjadi karena hasil REBA tidak bisa dibaca begitu saja, dan langsung diambil kesimpulan begitu saja, karena memungkinkan untuk terjadinya kesalahan misleading dalam menentukan rekomendasi utama yang akan diambil untuk mengatasi masalah ergonomic di tempat kerja. Sehingga data keluhan MSDs yang dirasakan para Teller menjadi verifikasi untuk hasil REBA yang didapatkan, yang akan membuat rekomendasi yang disarankan menjadi lebih tepat.

Kesimpulan lain terlihat bahwa layout peralatan, dan dimensi peralatan yang digunakan oleh Teller dalam bekerja tidak sesuai dengan prinsip ergonomi. 


\section{Faktor Individu Umur}

Keluhan MSDs mulai dirasakan pada usia kerja 25-65 tahun, dengan keluhan pertama biasanya dirasakan pada umur 35 tahun. Terdapat hasil penelitian yang menunjukkan bahwa kekuatan otot maksimal terjadi pada saat umur antara 2029 tahun . ${ }^{14}$

Rhiimaki dalam penelitiannya menemukan bahwa ada hubungan yang signifikan antara keluahan MSDs dengan umur pada operator mesin dan tukang kayu. Sebuah penjelasan bahwa hubungan antara peningkatan risiko MSDs dengan umur mungkin saja bisa menjadi bias, jika pekerja yang mempunyai masalah kesehatan keluar dari pekerjaan lamanya atau berpindah kerja pada pekerjaan yang sedikit risiko ergonominya.

\section{Jenis Kelamin}

Jenis kelamin merupakan factor yang berhubungan dengan timbulnya keluhan MSDs (7). Sejumlah penelitian yang melibatkan pekerja VDT mendapatkan hasil bahwa wanita berisiko lebih tinggi untuk terkena gejala pada tubuh bagian atas jika dibandingkan dengan laki-laki. Secara fisiologis, kemampuan otot lakilaki lebih besar dibandingkan dengan perempuan. Hubungan antara kekuatan fisik dengan timbulnya keluhan otot masih menjadi perdebatan. Namun secara fisiologi orang yang memiliki kekuatan fisik lebih rendah bila melakukan pekerjaan yang memerlukan pengerahan tenaga akan lebih rentan terhadap risiko cidera otot. Penelitian Eltayeb menunjukkan bahwa prevalensi rate perempuan pekerja komputer untuk terkena gejala MSDs 2 kali lebih tinggi dibandingkan laki-laki pekerja komputer.

\section{Kebiasaan}

\section{Pola Makan}

Manusia memerlukan zat gizi yang bersumber dari makanan. Secara khusus gizi yang dibutuhkan oleh pekerja adalah zat makanan yang bersumber dari bahan makanan yang diperlukan oleh tenaga kerja untuk memenuhi kebutuhan sesuai dengan jenis pekerjaan dan lingkungan kerja. $^{15}$

Untuk mempertahankan hidup dan dapat melakukan pekerjaan setiap orang membutuhkan tenaga. Tenaga tersebut diperoleh dari pembakan zat-zat makanan yang dikonsumsi dengan oksigen. Masalah yang mungkin timbul jika tidakseimbang antara makanan yang dikonsumsi dengan tenaga yang dikeluarkan sangat beragam. Jika makanan yang dimakan berlebih dibanding tenaga yang dikeluarkan maka tubuh akan menjadi gemuk. Seperti kita ketahui walaupun pengaruhnya kecil berat badan merupakan faktor yang dapat menyebabkan terjadinya keluhan otot skeletal. Wanita yang gemuk mempunyai risiko dua kali lipat dibandingkan wanita kurus. Dengan pola makan teratur 3kali sehari dengan keseimbangan antara makanan yang dikonsumsi dengan tenaga yang dikeluarkan maka risiko terkena gejala MSDs menjadi lebih kecil.

\section{Olah Raga}

Kebiasaan olah raga teratur erat kaitannya dihubungkan dengan kesegaran jasmani. $\mathrm{NIOSH}^{8}$ menjelaskan bahwa seseorang yang memiliki kapasitas aerobic yang tinggi maka akan memiliki kesesuaian dengan jenis pekerjaan yang membutuhkan tingkat oksigen tinggi, tapi kesesuaian itu tidak dibutuhkan pada pekerjaan yang membutuhkan ketahanan dinamis dan statis yang tinggi.

Kegiatan olahraga membutuhkan beban, gerakan repetisi dengan postur janggal sehingga perlu dilakukan studi lebih lanjut lagi terhadap kaitannya dengan gejala MSDs, karena studi NIOSH seperti pada kombinasi paparan yang tinggi terhadap factor risiko beban angkat pada kegiatan olahraga terkait erat dengan kejadian MSDs pada tendinitis bahu. ${ }^{8}$

\section{Konsumsi Vitamin dan Susu}

Pemenuhan nutrisi dan gizi termasuk kebiasaan mengkonsumsi vitamin seperti 
vitamin C, dan kebiasaan minum susu untuk pemenuhan kebutuhan akan Kalsium. Kedua nutrisi itu penting dalam hubungannya dengan pembentukan kepadatan tulang. Seperti pada satu penelitian yang menyimpulkan bahwa terdapat hubungan antara asupan kalsium dan massa tulang pada wanita premenopause.

Kalsium dibutuhkan untuk pertumbuhan normal dan perkembangan kerangka tubuh, juga penting untuk proses metabolis dan memberikan kekuatan mekanis pada tulang dan gigi. Kalsium bersama-sama dengan ATP berperan penting dalam kontraksi dan relaksasi otot. Dalam kontraksi, jika ATP sudah terpakai saat berkontraksi, maka secara anaerob jika oksigen tidak ada maka akan terbentuk asam laktat, yang bisa menyebabkan nyeri pada otot, karena tidak terjadi relaksasi otot.

Vitamin C berfungsi untuk stabilitas kolagen pada proses pembentukan tulang. Defisiensi vitamin C dihubungkan dengan terganggunya hubungan antar jaringan tubuh. Pada wanita pasca menopause dengan sejarah merokok dan penggunaan estrogen, peningkatan 1 standard deviasi kadar serum asam askorbat dapat dihubungkan dengan penurunan prevalensi patah tulang sebesar 45\%. Banyak dijual di pasaran vitamin $\mathrm{C}$ yang dikemas dengan kandungan Kalsium didalamnya. Sehingga diharapkan dengan konsumsi Vitamin C yang mengandung Kalsium, ataupun konsumsi susu akan menurunkan faktor risiko keluhan MSDs pada para pekerja.

\section{Keluhan Musculokeletal Disorders (MSDs)}

Keluhan MSDs pada kuesioner Nordic Body Map yang diisi oleh pekerja Teller PT. X banyak dikeluhkan pada daerah bahu, leher dan pinggang. Umumnya hanya merasakan pegal-pegal yang dirasakan pada saat melakukan pekerjaan ataupun setelah selesai bekerja, jika dihubungkan kemungkinan itu merupakan efek akut dari keluhan MSDs, hal itu terjadi karena pada saat melakukan kegiatan pekerjaan berdasarkan analisis ergonomi menggunakan metode REBA kebanyakan nilai terbesar risiko pada tubuh bagian atas seperti pada lengan atas, tangan dan pergelangan tangan yang berarti keluhan MSDs terkena pada otot kecil yang ada pada anggota tubuh bagian atas area lengan dan pergelangan tangan. Hal itu jika dikaitkan dengan pekerjaan Teller yang merupakan pekerjaan dengan karakteristik repetitive pada pekerjaannya dan kebanyakan dilakukan pada posisi duduk. Sejalan dengan penelitian yang dilakukan oleh Roeloefs pada Teller bank yang bekerja dominan dengan posisi duduk akan cenderung mengalami masalah MSDs pada bagian tubuh atas. ${ }^{14}$

Seperti pada task menghitung uang secara manual, menghitung uang dengan mesin hitung, memeriksa keaslian uang dan menyetorkan uang kepada supervisor setelah dianalisa dengan menggunakan metode REBA dikategorikan sebagai task yang memiliki risiko ergonomic tinggi. Kebanyakan skor tertinggi pada anggota tubuh kelompok B yaitu bahu, lengan dan pergelangan tangan yang semakin ditambah skornya disebabkan durasi dari beban statis pada satu anggota tubuh dan repetisi yang cukup tinggi, dikarenakan pada saat menghitung uang dengan jari manual biasanya jari bergerak dalam hitung detik, sehingga memungkinkan untuk repetisi lebih dari 4x dalam 1 menit.

Memang dari segi beban pekerjaan Teller tidak menerima beban berat, tetapi repetitive berkontribusi dalam menimbulkan keluhan MSDs. Faktor peralatan dan layout area kerja juga memberikan kontribusi yang cukup penting dalam menimbulkan keluhan MSDs, seperti pada penempatan monitor yang tidak sesuai dengan standar penempatan, yaitu harus sejajar dengan pandangan mata, dan leher tidak boleh menunduk. Tetapi dalam keseharian mereka bekerja hal itu sangat sering dilakukan, karena pekerjaan utama seorang Teller adalah menginput data transaksi ke 
dalam sistem komputer. Penempatan peralatan mesin hitung uang juga terlihat tidak ergonomis menyebabkan tubuh Teller harus memutar (twisting) sehingga semakin menambah tingginya nilai risiko ergonomi setelah dihitung dengan menggunakan metode REBA.

\section{Kesimpulan}

Berdasarkan temuan penelitian terdapat keselaran antara hasil analisa risiko MSDs dengan menggunakan metode REBA dan hasil kuesioner Nordic Body Map. Bahwa keluhan MSDs muncul pada anggota tubuh : leher, bahu dan pinggang yang merupakan implikasi dari postur janggal, frekuensi, durasi dan beban yang didapatkan oleh pekerja Teller bank dalam melakukan pekerjaannya.

Karakteristik individu yang berupa variasi umur, lama kerja, kebiasaan makan teratur, berolah raga teratur dan konsumsi susu dan vitamin secara teratur merupakan faktor pengganggu yang dapat meningkatkan risiko Teller terhadap keluhan MSDs.

\section{Saran}

Disarankan untuk melakukan perubahan layout peralatan kerja seperti monitor, alat hitung sesuai dengan prisinsip ergonomi. Menambahkan alat bantu seperti footrest dan document holder. Selain itu perlu dilakukan promosi kesehatan dalam bentuk merekomendasikan stretching pada saat bekerja setidaknya dilakukan setiap 2 jam sekali.

\section{Daftar Pustaka}

1. Anies. Penyakit Akibat Kerja. Jakarta: PT. Elex Media Komputindo; 2005.

2. Bridger RS. Introduction to Ergonomics. McGraw-Hill, Singapore; 2003

3. Hagberg M. Incidence of self-reported reduced productivity owing to musculoskeletal symptoms: association with workplace and individual factors among computer users. Ergonomics. London: Nov 2007. Vol. 50, Edisi 11; $\quad$ pg. 1820. http://proquest.umi.com/pqdweb?index=10\&did
$=1379373051 \&$ SrchMode $=1 \&$ sid $=17 \&$ Fmt $=2 \&$ VInst $=$ PROD \&VType $=$ PQD \&RQT $=309 \& V N a$ me=PQD\&TS=1274936024\&clientId=45625

4. Hwa Yun, Myung. Results of a survey on the awareness and severity assessment of upperlimb work-related musculoskeletal disorders among female bank Tellers in Korea. Department of Industrial Medicine, Wonjin Institute for Occupational and Environmental Health. South Korea; 2001.

5. Manuaba A. Shift Work at Hotels in Bali. Program Studi Ergonomi-fisiologi Kerja Universitas Udayana. Denpasar, Bunga Rampai Ergonomi. Vol. 2, 1998

6. McAtamney, Lynn \& Sue Hignett. Rapid Entire Body Assessment. In Neville Stanton et al. (Ed). Handbook of Human Faktors and Ergonomics Methods. USA: CRC Press. 2005

7. H. Miller. Musculoskeletal Disorders in the U.S. Office Workforce. 2001. http://www.pacificofficefurnishings.com/pdf/21 _Musculoskeletal.pdf

8. NIOSH. Element of Ergonomic Program, A Prime Based on Workplace Evaluation of Musculoskeletal Disorders. 1998. www.oshainfo.gatech.edu/

9. Oborne, David J,.. Ergonomics at Work: Human Faktor in Design and Development. England: John Wiley \& Sons Ltd. OSHA. 2000. Ergonomics: The Study of Work. US. Department of Labor. 1995.

10. Occupational Health Clinics for Ontarion Workers Inc.,. Office Ergonomics Handbook, $5^{\text {th }}$ edition. Ontario.2008.

11. Barbara A Plog., MPH, CIH, CSP.. Fundamentals of Industrial Hygiene. National Safety Council, Illinois. 1998.

12. Stepehen Pheasant. Bodyspace, Antropometry, Ergonomics, and the design of work, Taylor and Francis, London, Second Edition, 1998

13. Mustafa Pulat. Fundamentals of Industrial Ergonomics ( $2^{\text {nd }}$ ed.). USA: Waveland Press, Inc. Silverstein, B. \& Bradley E. 2006. Musculoskeletal Disorders. In Barry S. Levy et al (ed.). Occupational and Environmental Health: recognizing and Preventing Disease and Injury ( $5^{\text {th }}$ Edition.). Philadelphia: Lippincott Willian \& Wilkins. 1997.

14. Andres Roelefs. The Experience of Musculoskeletal Discomfort Amongst Bank Tellers Who Just Sit, Just Stand or Sit and Stand At Work. Australia. 2009 (di unduh : 10 Desember 2010) http://www.advantagebranch.com/PDFs/TheCh air.pdf

15. Bakri Tarwaka. Solichul HA. Ergonomi Untuk Keselamatan, Kesehatan Kerja dan Produktivitas. Jakarta; UNIBA Press; 2004. 